\title{
Wyrok Sądu Metropolitalnego w Katowicach (c. Sobański) z 23.02.2001 r. z tytułu błędu co do przymiotu bezpośrednio i zasadniczo zamierzonego
}

Ius Matrimoniale 7 (13), 227-231

2002

Artykuł został zdigitalizowany i opracowany do udostępnienia w internecie przez Muzeum Historii Polski w ramach prac podejmowanych na rzecz zapewnienia otwartego, powszechnego i trwałego dostępu do polskiego dorobku naukowego i kulturalnego. Artykuł jest umieszczony w kolekcji cyfrowej bazhum.muzhp.pl, gromadzącej zawartość polskich czasopism humanistycznych i społecznych.

Tekst jest udostępniony do wykorzystania w ramach dozwolonego użytku. 
Ius Matrimoniale

7 (13) 2002

\section{Wyrok Sądu Metropolitalnego w Katowicach (c. Sobański) z 23.2.2001 z tytulu blędu co do przymiotu bezpośrednio i zasadniczo zamierzonego}

\section{Przebieg sprawy:}

E.J. oraz A.G. zawarli małżeństwo $27.1 .1990 \mathrm{w}$ kościele św. P.P. w G. Ważność tego malżeństwa zaskarżył E.J. 18.10.1994 w Sądzie Kościelnym w G. z tytułu braku rozeznania oceniającego po stronie pozwanej. Sąd ten dekretem z 5.12.1994 oddalił skargę. Powód wniósł 15.12.1994 rekurs do Sądu Metropolitalnego W., który dekretem z 24.12.1995 (?) notyfikowanym powodowi 27.6.1995 (?) zatwierdził decyzję Sądu Kościelnego w G. Dnia 9.10.1995 oficjał Sądu Kościelnego w G. wyraził zgodę, by sprawa mogła być - po myśli kan.1673 n.3 - prowadzona w Sądzie Biskupim w K. Skarga powoda wpłynęła do Sądu Biskupiego w K. 25.10.1995. Jako tytuł prawny powód podal „błąd co do przymiotu pozwanej (jej rzekoma uczciwość) przechodząca w błąd co do jej osoby". Sąd przyjął sprawę do procesu 31.10.1995. Przedmiot sporu ustalono 21.11.1995 w formie pytania: czy zachodzi nieważność małżeństwa „z przyczyny błędu co do przymiotów osoby pozwanej przechodzącego w błąd co do jej osoby w danym przypadku". Wyrokiem z 12.2.1998 Sąd orzekl, iż nie udowodniono nieważności małżenstwa. Wskutek apelacji powoda z 9.3.1999 sprawa znalazla się w Sądzie Metropolitalnym w K. Odpowiadając na pytanie Sądu powód stwierdził, iż uważa małżeństwo „za niewazne z powodu tego, że pozwana nie była tą osobą, za jaką się podawała, kierując się oszustwem wprowadziła w błąd powoda co do jej osoby". Sąd Metropolitalny orzek1 1.9.1999 (cum voto separato), iz udowodniono nieważność małżeństwa. Na popartą przez Biskupa $\mathrm{K}$. oraz przez Oficjala Sądu Biskupiego w K. prośbę powoda Najwyższy Trybunał Sygnatury Apostolskiej reskryptem z 22.7.2000 wyznaczyi Sąd Metropolitalny w Katowicach do rozpatrzenia sprawy w trzeciej instancji. Akta sprawy nadeszly 5.9.2000 r. Dnia 20.9.2000 wyznaczono osobowy skład Sądu. Wobec braku nowych wniosków dowodo- 
wych zamknięto sprawę. Przyporządkowując stan faktyczny i normy prawa Sąd orzekt jak następuje:

\section{Prawny i faktyczny stan sprawy:}

1. Trybunał I instancji, rozpatrując sprawę na podstawie k.1097 §2, przyjął, że błąd, o którym w tym kanonie, może dotyczyć także jej „tożsamości moralnej”. Trybunał stwierdza w motywacji prawnej: „Trzeba bowiem wiedzieć, że pewne przymioty mogą dokładnie indywidualizować osobę i odróżnić ją od wszystkich łudzi, dzięki określonemu przymiotowi. Istotnym jest tu więc sam przymiot czy jego brak. Żeby orzec nieważność małżeństwa z przyczyny błędu co do przymiotu indywidualizującego osobę, muszą być dowody na to, że błąd taki rzeczywiście zaistnial. W omawianym przypadku chodzi o to, czy pozwana rzeczywiście ukryła przed powodem swoją przeszłość, a więc wprowadziła go w błąd i czy powód nigdy nie ożeniłby się, gdyby o tym wiedział".

Wyrok negatywny Trybunal uzasadnia tym, że powód w okresie narzeczeństwa nie interesowal się przeszłością pozwanej, a sam wobec Sądu zeznał, że gdyby wiedział, iż pozwana miała „w międzyczasie" dwa związki cywilne, to by się zastanowil, czy się żenić, ale nie wyklucza ożenku mimo posiadania takiej wiedzy. Sąd powołuje się ponadto na fakt, że przyczyną rozpadu małżeństwa nie bylo zorientowanie się powoda co do przeszlości pozwanej.

2. Sąd Metropolitalny prowadząc w sprawę w drugiej instancji uzupełnił instrukcję sprawy. Powód zarzucił nieadekwatne odnotowanie jego zeznań w I instancji, twierdząc, że mu ich nie odczytano, a podczas publikacji $z$ kolei on ich nie czytal! Zeznając w drugiej instancji podał, że wyklucza, aby się ożenił, gdyby wiedział o dwóch związkach cywilnych pozwanej „w międzyczasie”. Swiadkowie zeznający w II instancji potwierdzili, że powód „wziąlby każdą kobietę, również wdowę, ale nie rozwódkę". Zdaniem Sądu II instancji istotne dla sprawy jest pytanie, czy „powód istotną cechę osobowości pozwanej, wdowa czy rozwódka, tak traktowal, że gdyby wiedział o jej rozwodzie, ona nie bylaby dla niego osobą atrakcyjną". Na to pytanie Sąd udzielił odpowiedzi twierdzącej, konsekwentnie też orzekl nieważność małżeństwa.

3. Małżeństwo stron zostało zawarte w r.1990 a więc "za rządów" k.1097 §2, a nie k.1083 §2 n.1 CIC1917. Interpretując k.1097 §2 należy mieć na oku tradycję kanoniczną (k.6 \$2), zwłaszcza gdy chodzi o nor- 
my dotyczące kwestii tak trudnej, jak wpływ błędu co do przymiotu osoby na ważność małżeństwa. K.1097 §2 jest nową regulacją tej złożonej kwestii. Nie tracąc z oczu ciągłości dorobku orzecznictwa kościelnego, w którym zwraca się uwagę na znaczenie cech moralnych czy socjalnych dla identyfikacji osoby, nie wolno jednak interpretacji k.1083 $\$ 2$ n.1/CIC1917 aplikować do k.1097 \$2 bez zwrócenia uwagi na jego inne niz poprzednika sformułowanie. Kan. $1083 \$ 2$ n.1 koncentrował się na błędzie co do przymiotu powodującego, że poślubiony partner faktycznie był w oczach drugiej strony inną osobą: małżeństwo zostaje zawarte $z$ inną osobą, niż ta, którą zamierzano poślubić. Wśród czynników determinujących osobowość, wskutek których dotyczący ich (a więc przymiotu) błąd mógł stać się błędem co do osoby, orzecznictwo kościelne wskazywało na chorobę psychiczną, homoseksualizm, toksykomanię, alkoholizm, habitualną prostytucję, przy czym kryterium oceny stanowila waga - obiektywna i subiektywna - odnośnego przymiotu. Właśnie z tego nurtu orzecznictwa wyrósł k. 1097 \$2 CIC/1983. Norma ta dotyczy - oczywiście - błędu co do przymiotu, ale koncentruje się na zamiarze nupturienta: ważne jest nie tyle to, jaki to przymiot (także nie to, czy jest to przymiot „indywidualizujący osobę"), lecz chodzi o to, by był to przymiot wprost i bezpośrednio zamierzony. Nie musi to być przymiot ważki, istotne jest, że jawi się on jako szczególnie ważny w subiektywnej ocenie nupturienta. Wola małżeńska jest wtedy skierowana wprost i bezpośrednio na przymiot - wybiera się partnera ze względu na przymiot, a nie ze względu na niego samego: na pierwszym planie znajduje się przymiot, sama osoba i wszystkie inne jej cechy stają się przypadłością. „W postępowaniu dowodowym trzeba przeto wykazać faktyczne - a nie domniemane tylko skierowanie woli na obiekt (przymiot), co do którego zaszła pomyłka. Istotną rolę odgrywa oświadczenie samej zainteresowanej osoby, przy czym do Sądu należy ocena, czy owo ukierunkowanie woli na określony przymiot zachodziło faktycznie czy też jest - już w trakcie procesu retrospektywnie interpolowane, czyli przyjmowane hipotetycznie lub po prostu jest subiektywną interpretacją (voluntas interpretativa). Dla uzyskania odpowiedzi na te pytania trzeba sięgnąć w czas przed i poślubny: wyświetlić cechy osobowe nupturienta, przejętą przezeń hierarchię wartości, doświadczenia życiowe - wszystko to, co moglo wplynąć na ukierunkowanie woli na ów przymiot. Równie ważne są wydarzenia poślubne, wśród nich reakcja w chwili zorientowania się co do błędu" (Ius matrimoniale, 3/9/1998, 222). 
4. W skardze powód napisał, że przymiot pozwanej, co do którego się pomylił, to jej (rzekoma) uczciwość. Rozwijając swój zarzut pisze, iż „w haniebny sposób” oszukała go „twierdząc, że jest wdową, a była dwukrotną rozwódką". Takie twierdzenia nie dawały jednak podstaw do prowadzenia sprawy z tyt. $1097 \S 2$, gdyż uczciwość to wprawdzie ważny przymiot osoby, ale wprowadzenie w błąd co do stanu wdowiego, wzgl. rozwiedzionego, jest co prawda nieuczciwością, jednak nie uzasadnia generalizującego twierdzenia o nieuczciwości jako przymiocie osoby. Z kolei wprowadzenie w błąd, o którym pisze powód, nie uzasadnialo prowadzenia procesu z tyt. k.1098, gdyż stan wdowi wzgl. rozwiedziony to nie przymiot, który mógłby z natury swej zakłócić wspólnotę życia malżeńskiego. W piśmie apelacyjnym do II instancji twierdzi powód, że przyczyną rozpadu było „ukrycie przez pozwaną jej przeszlości” i wprowadzenie go w biąd „co do jej charakteru”, ale (1) nie wynika $z$ akt, by była to przeszłość taka, której echa mogłyby zakłócić późniejsze małżeństwo, zaś (2) co do cech charakteru sprawa była już oddalona przez Trybunaly w G. i w W. (a tylko gdyby wypaczenia charakteru odpowiadały normie k.1095 n.3, można by mówić o przymiocie $\mathrm{z}$ istoty swej zakłócającym wspólnotę małżeńską).

Nie chodzi więc w rozpatrywanej sprawie o to, czy pozwana wprowadziła powoda w błąd, lecz o to, czy powód był gotów ożenić się z każdą kobietą, byle nie z rozwódką. Nie ma o tym żadnej wzmianki w skargach, (także we wniesionej do Sądu w G.), przede wszystkim zaś przeczą temu zeznania złożone w Sądzie Biskupim w K. Tłumaczenie powoda, że mu zeznań nie odczytano, a mając akta do wglądu on ich nie czytal, jest pokrętne: jego podpis widnieje pod zwrotem „odczytane zeznania uznaję za swoje”, w tekście wprowadzono ręczne korekty, co świadczy, że jednak je czytano.

Dwoje świadków zeznało w drugiej instancji, że ,dla powoda ważne było to, żeby nigdy nie wziąć za żonę rozwódki”. Skoro „wdowa tak, rozwódka nie", to nasuwa się pytanie, w czym różnica. Wykluczenie rozwódki przy akceptacji wdowy ma sens tylko w odniesieniu do kwestii kanonicznego stanu wolnego. Katolik wykluczający rozwódkę daje przez to do zrozumienia, że nie związałby się związkiem wyłącznie cywilnym ( $\mathrm{z}$ osobą rozwiedzioną wprawdzie, ale związaną małżeństwem). Pozwana była kanonicznie osobą wolną, bo wdową. Nawet gdyby dać wiarę wyjaśnieniom powoda złożonym w II instancji, to nie widać, jak brak stanu „rozwiedziona” mógłby stać się przymiotem „wprost i bezpośrednio zamierzonym". 
Tak więc brak zarówno prawnych jak też faktycznych podstaw do uznania małżeństwa za nieważne w oparciu o kan. 1097 \$2. Tym samym Sąd orzeka, iż nie udowodniono nieważności malżeństwa i uchyla wyrok II instancji.

La sentenza del Tribunale Metropolitano di Katowice (c. Sobański) del 23.02.2001 dal titolo del errore circa la qualità della persona

\section{Sommario}

Si presenta il testo della sentenza del Tribunale Mertopolitano di Katowice c. Sobański ob errorem circa la qualità (,non constare”). 